drops to inhale. She made an uninterrupted recovery after delivery, and in six weeks' time was up and going about the house. The temperature during the puerperium was never above $1014^{\circ} \mathrm{F}$. The patient had ordinary treatment for pneumonia-i.e., hot poultices to chest, salines, early use of stimulants, with digitalis and tonics.

The following points in the case are worthy of note: The favourable result, exact date of rigor, labour set in after the crisis, cyanosis after delivery of head, and puerperal temperature. The temperature was taken for about four weeks after delivery.

\section{NOTE ON THE VALUE OF IGNIPUNCTURE IN THE TREATMENT OF HYPERTROPHIED CERVIX UTERI.}

By Alexander Duke, F.R.C.P.I., EX-ASSISTANT MASTER, ROTUNDA HOSPITAL ; GYNACOLOGIST, STEEVENS'S HOSPITAI.

THE length of time occupied by the usual routine treatment of a case of chronic hypertropied cervix uteri can be considerably shortened by the judicious use of ignipuncture. The usual plans of treatment-viz., tatmpons of glycerine, copious syringing with very little hot water, painting cervix with Churchill's tincture of iodine, \&c.-occupy a very considerable time, which prolonged treatment (unless the patient is able and willing to pay for) "is more honoured in the breach than the observance." Superficial firing by canstics or smouldering pieces of carbon held in contact with cervix by forceps is not sufficient in well-marked cases of chronic hypertrophy to obtain the desired result within a reasonable time. Having observed the good effects on enlarged tonsils by the employment of ignipuncture, I have given it a trial, and can strongly recommend it as a useful adjunct in these cases. A thermo-cautery of small size and point (Paquelin's) will be found the best for the purpose, but those who do not possess this valuable instrument can obtain equally good results with a copper rod, sharp at the point, and with solid bulb about half an inch from the top, so as to retain the heat while the necessary number of punctures are made through a wooden or celluloid cylindrical speculum. This cautery can be heated with an ordinary spirit lamp till red-hot, held in the tissues for a few seconds, while each puncture, about a quarter of an inch, is made, and then withdrawn. There should be no bleeding observable if the operation has been properly performed, such being caused by the cautery being either too hot or too cold. My usual practice is to blow a little boric acid (with my vaginal insufflator) over the punctured surface, and make no examination for about a week, when the operation can be repeated if necessary. I have also found ignipunctiure of great value in lacerations of the cervix when hardly bad enough todemand Emmet'soperation. Little pain, if any, is produced unless the operator is unwise enough to allow the patient to observe the preliminaries. Dublin.

\section{de gitlirror \\ OF}

\section{HOSPITAL PRACTICE, BRITISH AND FOREIGN.}

Nulla autem est alia pro certo noscendi via, nisi quamplurimas et mor. borum et dissectionum historias, tum aliorum tum proprias collectas habere, et inter se comparare.-MorGaGin De Sed. et Caus. Morb., lib. iv. Procemium.

\section{CHARING-CROSS HOSPITAL.}

NEPHRO-LITHOTOMY ; TWENTY CALCULI REMOVED FROM THE LEFT KIDNEY; RECOVERY.

(Under the care of Mr. JoHN H. MoRGAN.)

IT is evident that this patient has from a very early age been a victim to a defective elimination of certain excreta. Before 1871 he had suffered from premonitory attacks, but in that year he experienced pain in the right kidney, and during a severe illness in October, 1882, when he was attended by Dr. Lionel Beale, who has favoured Mr. Morgan with notes of the case, he passed a rough stone about the size of a bean, and consisting of brittle phosphates throughout, after which the urine often contained phosphates and frequently blood-corpuscles. It was not until 1889 that pain was referred to the left kidney, which was not aggravated by jolting, and in Angust of that year the urine, sp. gr. 1020, was found to contain oxalate of lime crystals and a slight amount of albumen, with a few bloodcorpuscles. The subsequent history is given below, and has been kindly furnished by Dr. Grinling Bunn of Norwood, who prevailed upon him to consult Mr. Morgan, with the result here given. The state of the kidney, as ascertained at the operation, showed remarkably little disorganisation, and it seemed extraordinary that such a quantity of calculi could be formed in so short a period as the history indicates, and should not have interfered to a greater extent with the outflow of urine from the pelvis. The larger stone certainly projected down the ureter, and the smaller ones lay below and behind it, but the kidney was not enlarged and the pelvis but little dilated, while the pyramids were little altered from their usual size and shape. The patient has already improved greatly in health and strength, and if he can correct the tendency to the formation of deposits there is every hope that he may look forward to a healthy and useful life. For the following notes we are indebted to Mr. Parham, surgical registrar.

W. J. G-, a well-nourished man, but anæmic and careworn, was admitted on June 11th. His antecedents were gouty and his mother died of phthisis. $\mathrm{He}$ is now forty-three years of age, but from childhood has suffered from calculous symptoms. When about seventeen or eighteen he suffered from paroxysmal pains in the left loin, lasting from half an hour to an hour, shooting down the front of the abdomen, but not, as a rule, into the testis. These were accompanied by vomiting and fits of shivering. During and after the paroxysm the urine was passed frequently, and in large quantity, occasionally containing gravel, sometimes accompanied with blood, either in large quantities or only enough to make the urine smoky. Up to the age of twenty there were five or six such attacks, lasting from two to six weeks, always ending with the passing of $a$ stone. At the age of twenty a more severe attack occurred, lasting about nine weeks, during which he was attended by Dr. Lionel Beale. The pain was then referred to the region of the right kidney, and ceased on the passing of a small calculus. Up to three years ago he has had comparative immunity, and has been able to walk and drive without pain, the urine being always clear. At that time, however, there was a return of the pain in the left loin, accompanied by vomit. ing, but no hæmaturia, the attacks being followed by polyuria. For the first eighteen months the paroxysms recurred variably every week or month, after which they became less frequent. A year ago he was compelled to leave his business on account of the pain in the left loin, which was always aggravated at night, and when the bowels were confined. Latterly the pain, though severe, has not had the same paroxysmal character as formerly, has not been accompanied by vomiting, shivering, or hæmaturia, and has not been accentuated by exercise. He has been obliged to rise once or more in the night to pass urine during the last few years. On examination there was found a spot, situate about two inches from the line of the vertebræ and a little below the first rib, where pressure caused distinct pain, no pain being felt on pressing over the anterior surface of the left kidney. The urine was neutral, sp. gr. 1018, a trace of albumen, no sugar, slight amount of mucus. Some oxalate of lime crystals were seen under the microscope, and a very few corpuscles of blood. He left the hospital for a few days to arrange his affairs, and on readmission the evidence of local tenderness was confirmed. After the examination he complained of pain running down to the left testis, and the urine showed a few more blood.cells and pus-corpuseles besides the crystals of oxalate of lime. On June $26 \mathrm{th}$ he had a severe paroxysm of pain, during which he vomited twice.

On July 4th Mr. Morgan operated, making an incision four to five inches in length parallel with the last rib and about half an inch below it, commencing at the outer border of the erector spinæ, and dividing the inner fibres of the quadratus lumborum. The peri-nephritic fat was abundant, and was torn through and the kidney explored with the finger. A stone was at once felt in the pelvis; but, owing to the depth at which the kidney lay, it was exceedingly difficult to fix the organ before incising. This was done by seizing 